\title{
Selective cyclooxygenase- 2 inhibitors inhibit growth and induce apoptosis of bladder cancer
}

\author{
JASON GEE ${ }^{1}$, I-LING LEE ${ }^{1}$, DAVID JENDIROBA ${ }^{2}$, SUSAN M. FISCHER ${ }^{3}$, \\ H. BARTON GROSSMAN ${ }^{1}$ and ANITA L. SABICHI ${ }^{4}$ \\ Departments of ${ }^{1}$ Urology, ${ }^{2} \mathrm{GU}$ Medical Oncology, ${ }^{3}$ Carcinogenesis and ${ }^{4}$ Clinical Cancer Prevention, \\ The University of Texas M.D. Anderson Cancer Center, Houston, TX 77030, USA
}

Received August 11, 2005; Accepted September 16, 2005

\begin{abstract}
Selective COX-2 inhibitors such as celecoxib and NS-398 are being evaluated as chemopreventive and therapeutic agents for bladder and other cancers. We investigated the effects of these nonsteroidal anti-inflammatory agents on a panel of bladder cancer cell lines, and assessed their effects on anchorage-dependent and -independent growth, cell cycle, apoptosis and morphology. The human bladder cancer cell lines UM-UC-1, -3 , and -6 were assayed for COX-2 expression by Western analysis using a monoclonal antibody to COX-2. UM-UC-1, -3 , and -6 cells were grown in the presence of increasing concentrations of NS-398 and celecoxib, and cell growth was quantitated over 7 days by crystal violet elution. The cell lines were treated with NS-398 and celecoxib for $48 \mathrm{~h}$ and analyzed by flow cytometry with propidium iodide staining and $\mathrm{Br}-\mathrm{dUTP}$ staining for apoptosis. Anchorage-independent growth was assessed using an agarose growth assay. Western analysis demonstrated that COX-2 expression in UM-UC-1, -6 , and -3 was high, low, and undetectable, respectively. NS-398 and celecoxib produced dose-dependent growth inhibition of UM-UC-1 and -6. Both NS-398 and celecoxib also inhibited anchorage-dependent and -independent growth of UM-UC-3 in a dose-dependent fashion, despite the low basal expression of COX-2 in this cell line. Cell cycle analyses of UM-UC- 1 and -6 revealed a $50 \%$ reduction in S-phase in the presence of $100 \mu \mathrm{M}$ NS-398 whereas a smaller reduction in S-phase was noted in UMUC-3 cells. Furthermore, treatment with $100 \mu \mathrm{M}$ celecoxib resulted in significant apoptosis in all three cell lines, which was associated with downregulation of Bcl-2. COX-2 selective inhibitors NS-398 and celecoxib produced dosedependent growth inhibition of bladder cancer cells associated with a significant reduction in S-phase. Induction
\end{abstract}

Correspondence to: Dr Jason Gee, Division of Urology, Department of Surgery, University of Wisconsin Hospital and Clinics, 600 Highland Avenue CSC G5/342, Madison, WI 53562, USA

E-mail: gee@surgery.wisc.edu

Key words: cyclooxygenase-2 inhibitors, apoptosis, bladder cancer of apoptosis in all three cell lines by celecoxib was associated with downregulation of Bcl-2. These changes occur independently of COX-2 expression levels suggesting the presence of a COX-2 independent pathway.

\section{Introduction}

Nonsteroidal anti-inflammatory drugs (NSAIDs) have shown great promise as chemopreventive agents for colon and other cancers. Patients who use NSAIDs on a regular basis have a lower relative risk of adenomatous polyps and colorectal cancer $(1,2)$. Regular intake of NSAIDs has also been associated with a decreased risk of bladder cancer (3).

NSAIDs are thought to exert their anti-inflammatory and anti-neoplastic effects by inhibiting the cyclooxygenase enzyme of which there are two isoforms, COX-1 and COX-2. The COX-1 gene is expressed in normal tissues and contributes to homeostasis. COX-2 is not normally expressed, but it is upregulated by inflammation and is associated with neoplasia. COX-2 may contribute to tumor growth and progression by increased production of prostaglandins and downstream mediators that enhance growth, angiogenesis, invasion, and resistance to apoptosis $(4,5)$.

Nonselective NSAIDs such as aspirin and ibuprofen inhibit both COX-1 and COX-2. COX-1 inhibition can result in gastritis and bleeding secondary to platelet dysfunction. To limit COX-1-related toxicity, there has been interest in the use of selective COX-2 inhibitors for chemoprevention (6-8). Recent publicity regarding cardiovascular toxicity of COX-2 inhibitors has curtailed the evaluation of this class of agents in prevention studies (9). However, the COX-2 selective inhibitor celecoxib has been found to be relatively safer than other agents in its class such that it has remained on the market and continues to be evaluated in a prospective chemoprevention trial for superficial bladder cancer (10). More recently, celecoxib has also been evaluated in combination with standard chemotherapeutic agents in multiple tumor types (11-13), and in this setting, any additional long-term cardiovascular risk should be weighed against the benefits of treatment in patients with advanced disease. Here, we examine the biologic effects of two COX-2 selective inhibitors, NS-398 and celecoxib, on bladder cancer cell lines that exhibit various levels of COX-2 expression. 


\section{Materials and methods}

Cell culture. The bladder cancer cell lines UM-UC-1, UMUC-3, and UM-UC-6 (14) were maintained in modified Eagle's medium containing penicillin-streptomycin and $1 \%$ fetal bovine serum. The UM-UC-1 cell line was derived from metastatic bladder cancer whereas UM-UC-3 and UM-UC-6 were derived from bladder TUR specimens. Dimethyl sulfoxide (DMSO) was used as the vehicle for both NS-398 and celecoxib.

$P G E_{2}$ production. Cells were plated on 6-well plates at a density of $2 \times 10^{5}$ cells per well. After $24 \mathrm{~h}$, the medium was exchanged with media containing either $100 \mu \mathrm{M}$ of NS-398, $50 \mu \mathrm{M}$ of celecoxib, or DMSO alone. Media was harvested $48 \mathrm{~h}$ following treatment and analyzed by ELISA (Assay Designs, Ann Arbor, MI) in triplicate.

Cell proliferation. Cells were plated on $96-$ well plates $\left(2 \times 10^{3}\right.$ cells per well). After $24 \mathrm{~h}$, the cells were treated with $0,12.5$, 25 or $50 \mu \mathrm{M}$ of celecoxib; with $0,50,100$ or $200 \mu \mathrm{M}$ of NS398; or with DMSO alone. The cells were fixed in $1 \%$ glutaraldehyde in phosphate-buffered saline (PBS) at 24-h intervals and stained with crystal violet. The dye was then eluted with Sorenson's solution ( $0.03 \mathrm{M}$ sodium citrate, $0.02 \mathrm{~N}$ $\mathrm{HCl}$, and $45 \%$ ethanol), and absorbance was read at $540 \mathrm{~nm}$.

Cell cycle. Cells were grown in $10 \mathrm{~cm}$ dishes to $70 \%$ confluence and treated with $50-100 \mu \mathrm{M}$ of celecoxib, 100$200 \mu \mathrm{M}$ of NS-398, or DMSO alone for $48 \mathrm{~h}$. The cells were then harvested by trypsinization. Floating cells were recovered from the supernatant. The cells were washed twice with PBS and fixed in $1 \%$ paraformaldehyde in PBS at $4^{\circ} \mathrm{C}$ for $20 \mathrm{~min}$. They were then washed twice with PBS, resuspended in $70 \%$ ethanol, and stored at $-20^{\circ} \mathrm{C}$ overnight. The cells were then washed twice with PBS, resuspended in a $1 \mathrm{ml}$ solution containing $50 \mu \mathrm{g} / \mathrm{ml}$ of propidium iodide and $20 \mu \mathrm{g} / \mathrm{ml}$ of RNAse A in PBS, and incubated for $30 \mathrm{~min}$ at $37^{\circ} \mathrm{C}$ prior to flow cytometry. Apoptosis was determined with the APO-BRDU kit (Phoenix Flow Systems, San Diego, CA).

Clonigenic assay. Cells $\left(1 \times 10^{4}\right)$ were plated on 6-well dishes in triplicate in $0.4 \%$ seaplaque agarose (Biowhittaker, Rockland, ME) containing $10 \%$ fetal bovine serum with a $0.53 \%$ agarose bottom layer. NS-398, celecoxib, or DMSO was distributed in the agarose solution prior to plating. Growth was assessed at 14 days. Colonies were photographed with digital microscopy using an inverted microscope and were manually counted in triplicate wells. Counting was confirmed independently using digital image analysis software (NIH image version 1.61).

$R T$-PCR. Cells were grown to subconfluence in $10 \mathrm{~cm}$ dishes. Total RNA was harvested according to standard protocol (15), and RT-PCR was performed as previously described (16) using primers for COX-1. The 5' primer was 5'-CAGACGACCC GCCTCATCCTCATAG-3', and the 3' primer was 5'-GCC TCAACCCCATAGTCCACCAACA-3'. Amplified DNA fragments were resolved on a $1 \%$ agarose gel and visualized with ethidium bromide.
A

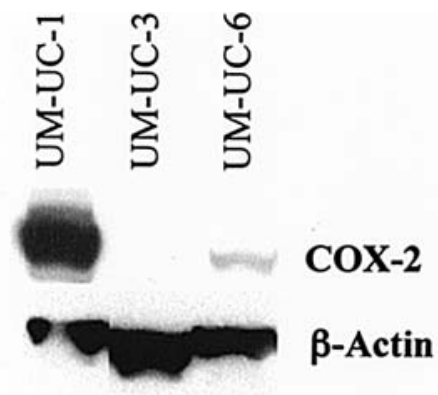

B

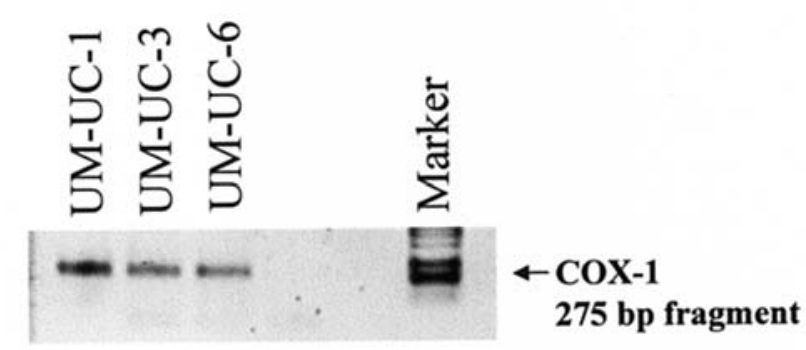

Figure 1. Basal COX-2 expression in UM-UC-1, -3 , and -6 by Western analysis (A). Basal COX-1 expression in UM-UC-1, -3 , and -6 by RT-PCR amplification of a 275-bp COX-1 coding region segment using primers: 5'CAGACGACCCGCCTCATCCTCATAG-3' and 5'-GCCTCAACCCCAT AGTCCACCAACA-3' (B).

Western analysis. Protein was harvested as previously described (17) and was denatured at $100^{\circ} \mathrm{C}$ for $5 \mathrm{~min}$ in a sample buffer containing $\beta$-mercaptoethanol prior to loading on $10 \%$ polyacrylamide gels. Following electrophoresis at 80-100 V, protein was transferred to a nitrocellulose membrane. Membranes were then probed with antibodies to Bcl-2 (Santa Cruz Inc., Santa Cruz, CA), COX-1, and COX-2 (Cayman, Ann Arbor, MI).

\section{Results}

COX-1 and COX-2 expression levels for UM-UC-1, UMUC-3, and UM-UC-6 were determined by Western analysis. Whereas, UM-UC-1 and UM-UC-6 had high- and low-levels of COX-2 expression, respectively; COX-2 was undetectable in UM-UC-3. COX-1 expression was undetectable by Western analysis in all three cell lines. However, RT-PCR revealed the presence of COX-1 mRNA in all three cell lines, suggesting a low basal expression of this enzyme (Fig. 1B).

Basal prostaglandin $\mathrm{E}_{2}\left(\mathrm{PGE}_{2}\right)$ levels measured in the medium reflected the levels of COX-2 expression in the cell lines. The highest $\mathrm{PGE}_{2}$ level was found in UM-UC-1 $(12,030 \mathrm{pg} / \mathrm{ml})$, followed by UM-UC-6 $(59 \mathrm{pg} / \mathrm{ml})$ and UMUC-3 $(20 \mathrm{pg} / \mathrm{ml})$. Following treatment of cells with either NS-398 or celecoxib for $48 \mathrm{~h}, \mathrm{PGE}_{2}$ levels were significantly reduced for UM-UC-1 and UM-UC-6 (Fig. 2). However, $\mathrm{PGE}_{2}$ levels for UM-UC-3 were unchanged.

Both NS-398 and celecoxib inhibited the growth of all three cell lines in a dose-dependent fashion (Fig. 3). The $\mathrm{IC}_{50}$ of celecoxib was $25 \mu \mathrm{M}$ for all three cell lines, and the $\mathrm{IC}_{50}$ of NS-398 was $75 \mu \mathrm{M}$ for UM-UC-1 and $100 \mu \mathrm{M}$ for UM-UC-3 and UM-UC-6. Growth inhibition was independent of baseline COX-2 expresssion. 

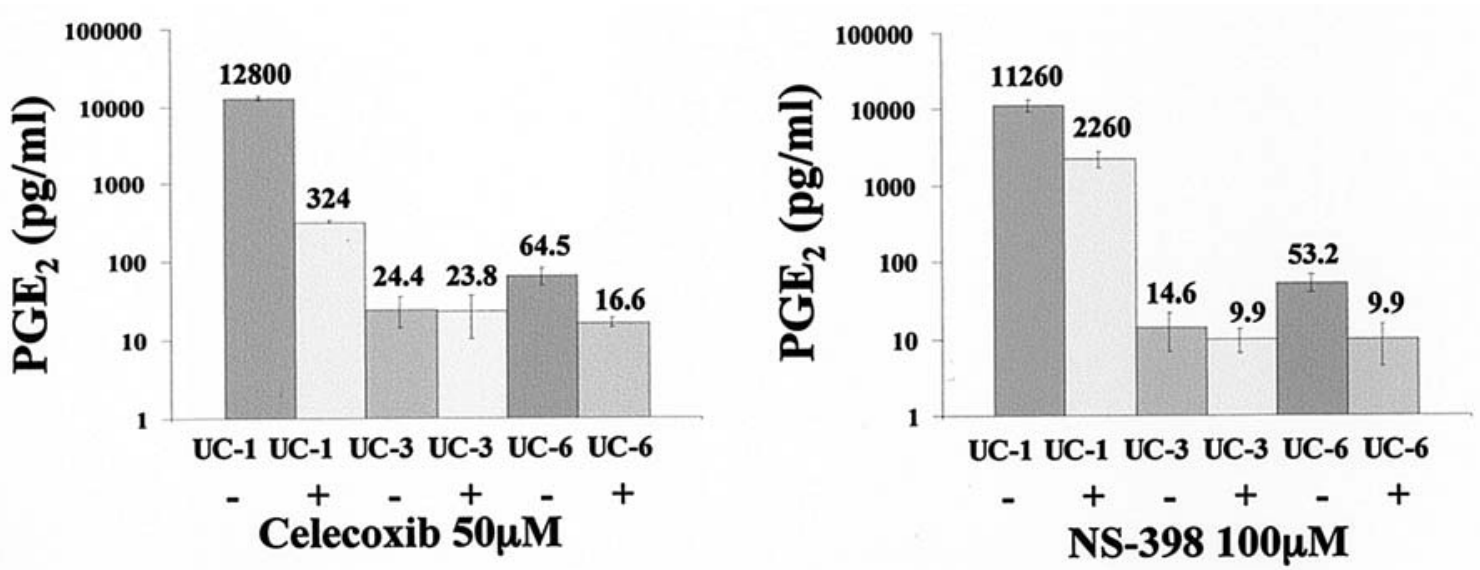

Figure 2. Prostaglandin $\mathrm{E}_{2}$ levels as measured by ELISA in the supernatants of UM-UC-1, -3, and -6.

Celecoxib
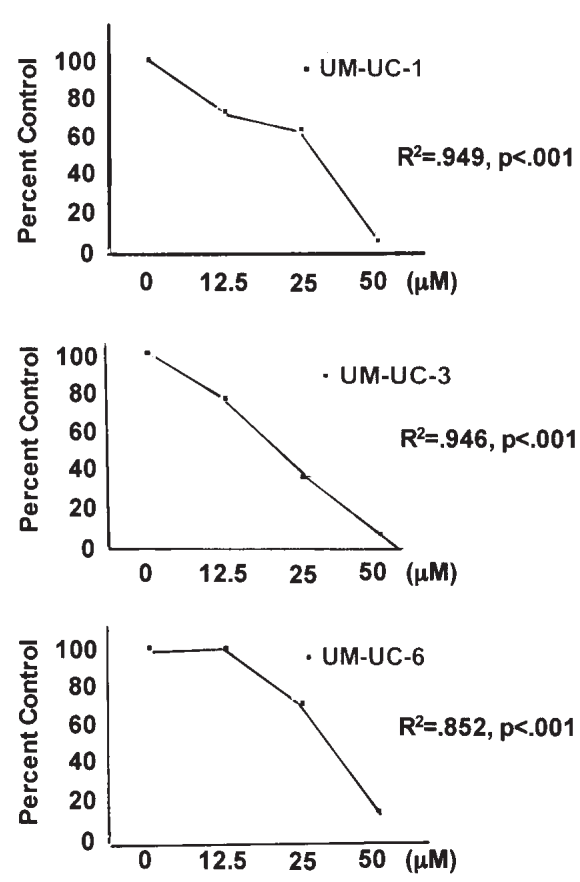

NS-398
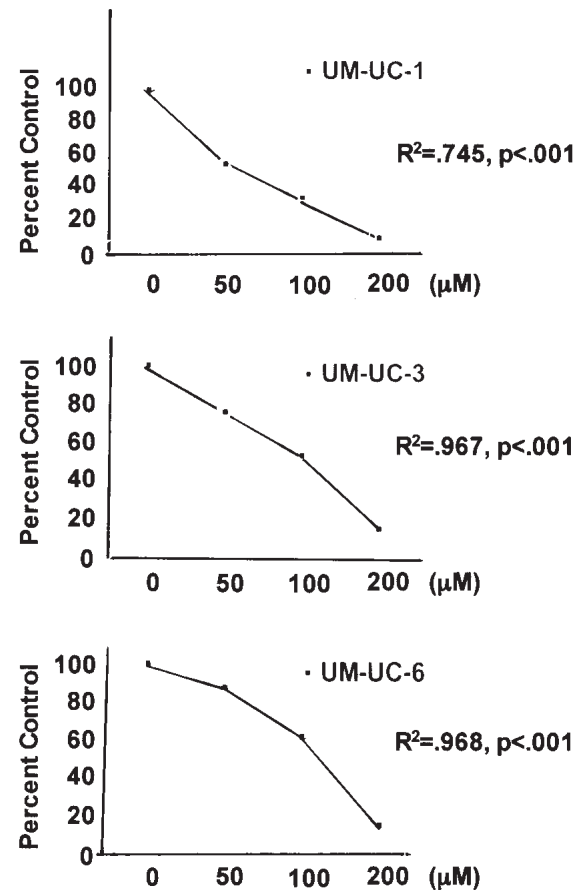

Figure 3. Growth inhibition by celecoxib and NS-398. Graphs represent the percentage of growth relative to control (DMSO only). Linear regression revealed a statistically significant correlation $\left(\mathrm{R}^{2}=0.75-0.97, \mathrm{p}<0.001\right)$ for each cell line.

Following treatment with $100 \mu \mathrm{M}$ of NS-398 for $48 \mathrm{~h}$, UM-UC-1, -3 , and -6 cells exhibited a decrease in the S-phase population of 44,25 , and $16 \%$, respectively. This decrease in S-phase was associated with a 42 and $53 \%$ increase in the G2$\mathrm{M}$ population for UM-UC-1 and UM-UC-3, respectively, whereas a $24 \%$ increase in the G0-G1 population was noted for UM-UC-6 (Fig. 4). Apoptosis was not observed in any of these cell lines following treatment with concentrations of NS-398 $\leq 200 \mu \mathrm{M}$ for $48 \mathrm{~h}$. NS-398 precipitated out of solution when concentrations $>200 \mu \mathrm{M}$ were used.

In contrast, treatment with $100 \mu \mathrm{M}$ of celecoxib induced apoptosis in UM-UC-1 and UM-UC-3, with a lesser degree of apoptosis observed for UM-UC-6 (Fig. 5). Treatment of UMUC-6 with $100 \mu \mathrm{M}$ of celecoxib resulted in a $21 \%$ decrease in S-phase for this cell line, with a corresponding $21 \%$ increase in the G0-G1 population. Apoptosis was not detected for these cell lines in the presence of $50 \mu \mathrm{M}$ celecoxib. However, decreased levels of Bcl-2 expression were observed in all three cell lines in the presence of 25-50 $\mu \mathrm{M}$ of celecoxib (Fig. 6) and $100 \mu \mathrm{M}$ of NS-398 (data not shown).

NS-398 and celecoxib were both effective in reducing the number and size of UM-UC-1 and UM-UC-3 colonies in soft agarose in a dose-dependent fashion. However, only celecoxib significantly reduced UM-UC-6 colony formation (Fig. 7). 

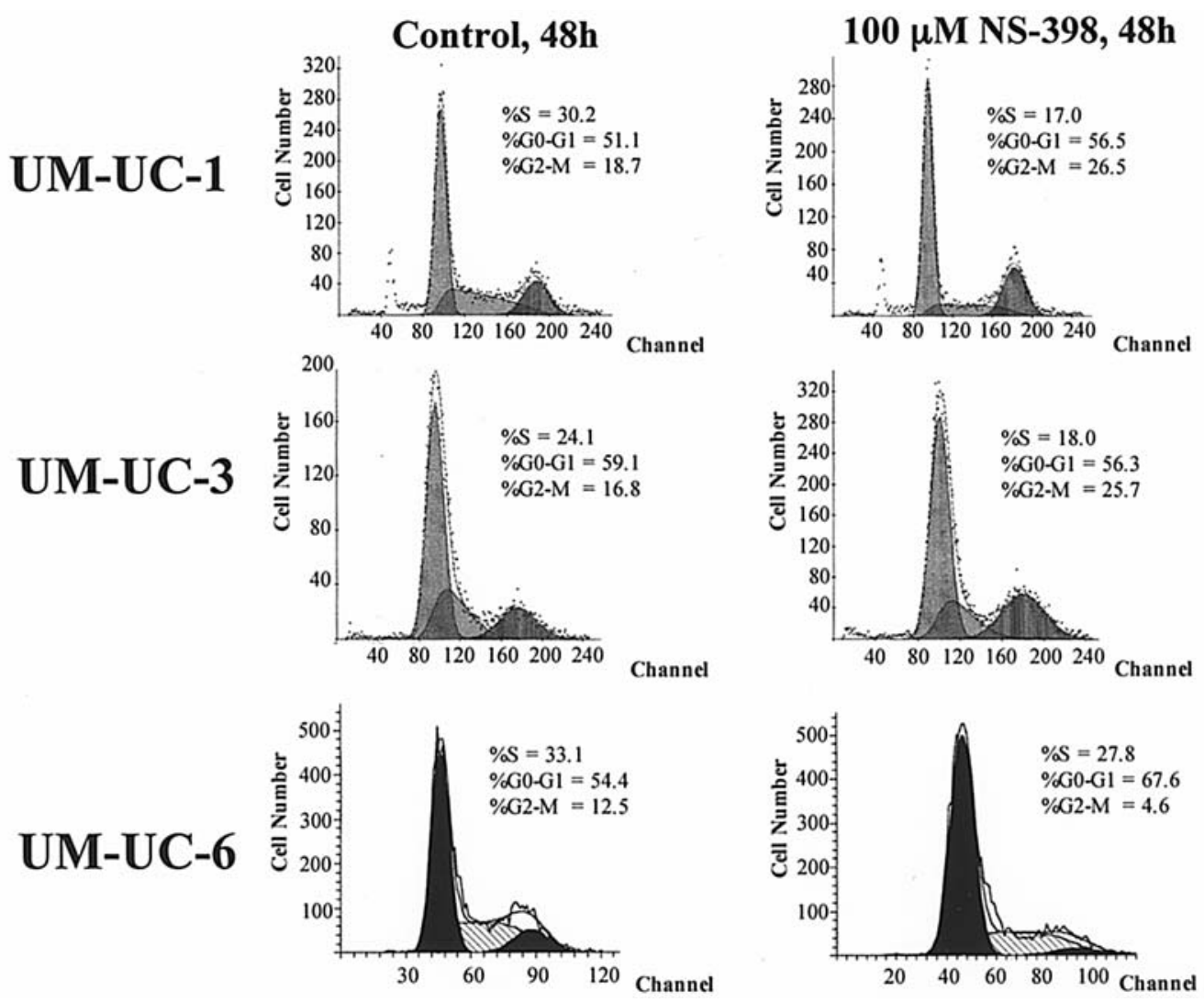

Figure 4. Cell cycle distributions demonstrating a decrease in S-phase following treatment with $100 \mu \mathrm{M}$ of NS-398.

\section{Discussion}

Overexpression of the COX-2 enzyme occurs in a variety of tumors. Forced expression of COX-2 in colon carcinoma cells has been shown to enhance invasion and induce resistance to apoptosis. These findings are associated with changes in the expression of downstream mediators such as Bcl-2, VEGF, matrix metalloproteinases, and E-cadherin (18-20). Excess prostaglandin production by COX-2 is thought to contribute to the malignant phenotype. The treatment of colorectal carcinoma cell lines with $\mathrm{PGE}_{2}$ results in enhanced growth, motility, invasion, and resistance to apoptosis (21-23).

In this study, we evaluated the biologic effects of two structurally different COX-2 selective inhibitors, celecoxib and NS-398, on bladder cancer cells. Two of the cell lines, UMUC-1 and UM-UC-6, expressed COX-2 at high- and lowlevels, respectively. $\mathrm{PGE}_{2}$ levels in the medium paralleled the levels of cellular expression of COX-2. Treatment with celecoxib and NS-398 significantly reduced the $\mathrm{PGE}_{2}$ produced by these cell lines and significantly inhibited anchoragedependent and -independent growth. Celecoxib, but not NS398 , induced apoptosis in these cell lines. NS-398 and celecoxib inhibited the growth of UM-UC-3 cells and celecoxib induced apoptosis in this cell line, which does not express detectable levels of $\mathrm{COX}-2$, suggesting that these agents may also work via a COX-2-independent pathway in bladder cancer. Because COX-2 inhibitors have varying degrees of selectivity for the COX-2 isoform, it is possible that COX-1 inhibition may account for some of this effect (24-26).
At the relatively high doses used in this study, these agents may also have inhibited the COX-1 enzyme.

There is evidence indicating that NSAIDs may work independently of COX. Sulindac sulfone, a metabolite of the NSAID sulindac sulfide, affects neither COX-1 nor COX-2 but inhibits growth and induces apoptosis in colon carcinoma cells (27). Furthermore, celecoxib has been shown to inhibit cell cycle progression and to induce apoptosis in colon cancer cell lines lacking COX-2 (28). Additionally, NS-398 has been shown to induce apoptosis in colon cancer cells lacking COX-2 expression (29). NSAID concentrations at which antitumor effects such as induction of apoptosis, cell cycle inhibition, and inhibition of angiogenesis are seen may be 100- to 1000-fold higher than that necessary to inhibit $\mathrm{PGE}_{2}$ synthesis, which may indicate an effect on other molecular pathways (30). Structural modifications of celecoxib, in which the terminal phenyl group was replaced with various substituents, demonstrated a wide range of apoptotic activity for these derivative compounds (31). Apoptotic activity was unrelated to COX-2 inhibitory activity of these compounds. NS-398 and celecoxib have been reported to inhibit the COX-2 enzyme $\left(\mathrm{IC}_{50}\right)$ with a range of 0.1-0.9 $\mu \mathrm{M}(30)$. However, we found that concentrations of NS-398 ranging from 25 to $200 \mu \mathrm{M}$ were necessary to inhibit the growth of bladder cancer cells, and growth inhibition and induction of apoptosis in the presence of celecoxib occurred at concentrations ranging from 12.5 to $100 \mu \mathrm{M}$. Growth inhibition occurred in a dose-dependent fashion with a statistically significant correlation by linear regression analysis $\left(\mathrm{R}^{2}=0.75-0.97\right.$, $\mathrm{p}<0.001)$. Our findings are consistent with that of Williams 
A
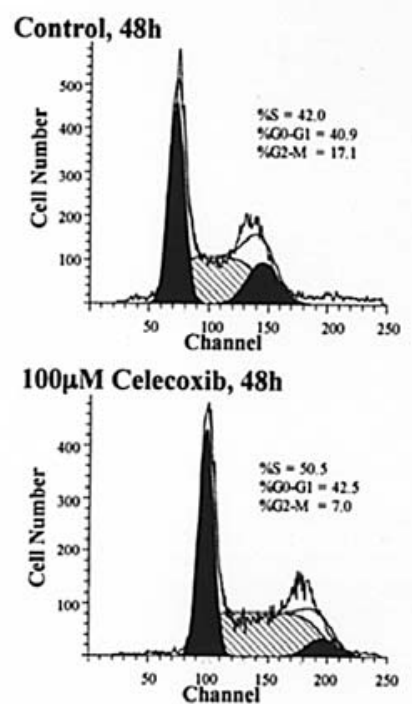

UM-UC-1
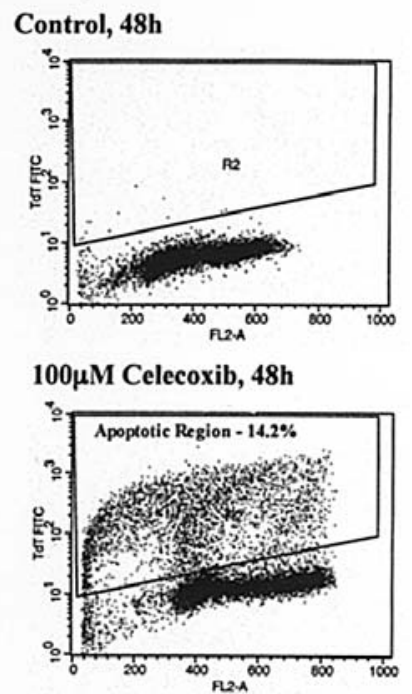

B
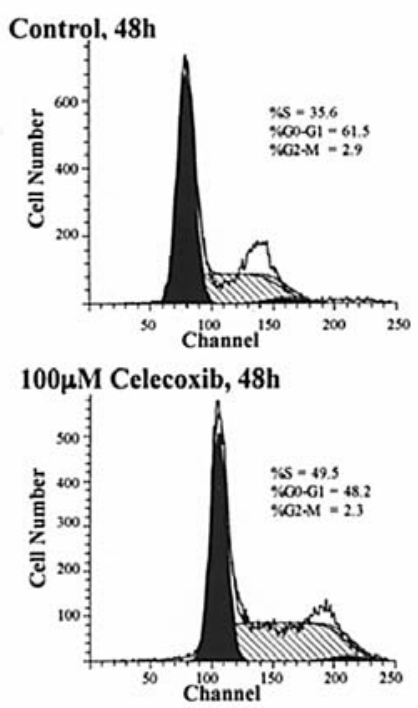

C
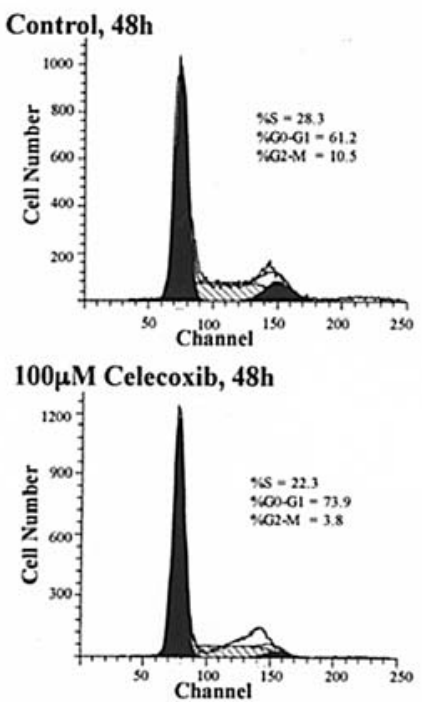

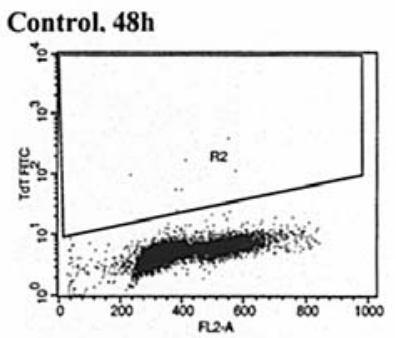

$100 \mu \mathrm{M}$ Celecoxib, $48 \mathrm{~h}$

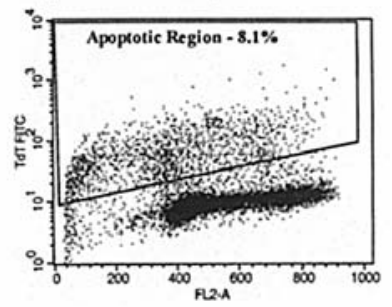

et al (28), in which in vitro concentrations of celecoxib as well as other NSAIDs ranging from 25 to $100 \mu \mathrm{M}$ were required to produce growth inhibition and apoptosis in colon carcinoma cells. They also found that serum concentrations of only 2-3 $\mu \mathrm{M}$ celecoxib were sufficient to inhibit the growth of colon carcinoma xenografts in nude mice, illustrating the importance of in vivo factors in this process (28). Increased efficacy in vivo may result from an anti-angiogenic effect (32). The efficacy of celecoxib in reducing bladder cancer incidence and growth in vivo has also been reported by Grubbs et al (33).

We found that celecoxib downregulates Bcl-2 in bladder cancer cells. Downregulation of Bcl-2 and induction of apoptosis have also been reported following treatment of the prostate carcinoma cell line LNCaP with NS-398 (34). Alternative molecular targets for COX-2 inhibitors that have

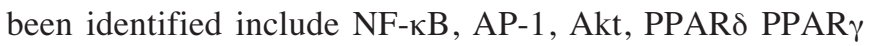
and STAT1 $(29,35,36)$. No significant change in PPAR $\gamma$ expression in the presence of COX-2 inhibitors was identified by Western analysis (data not shown). Furthermore, there has been recent interest in the 15-lipoxygenase enzyme as an alternate mechanism by which NSAIDs may induce apoptosis. Detectable expression of 15-lipoxygenase was not observed in any of the bladder cancer cell lines in this study (data not shown). However, in vitro studies of esophageal carcinoma as well as colon carcinoma have demonstrated that NSAID treatment with both COX-2 selective and nonselective inhibitors upregulates the 15-lipoxygenase enzyme $(37,38)$.

Biologic differences were demonstrated for the two COX-2 selective NSAIDs in this study. Although both agents produced significant growth inhibition of the bladder cancer cells, a decrease in S-phase was observed consistently only for NS398, suggesting differing mechanisms of growth inhibition for

Figure 5. Induction of apoptosis in UM-UC-1 in the presence of $100 \mu \mathrm{M}$ celecoxib (A). Induction of apoptosis in UM-UC-3 in the presence of $100 \mu \mathrm{M}$ celecoxib (B). Apoptosis is seen to a lesser extent in UM-UC-6 in the presence of $100 \mu \mathrm{M}$ celecoxib (C). these two agents. Furthermore, apoptosis was observed only in cells treated with celecoxib. In prostate cancer, growth inhibition and rapid cellular changes consistent with apoptosis were observed within $2 \mathrm{~h}$ of treatment with celecoxib but were seen only after cells were exposed to NS-398 for 120 h (39). Structural differences of celecoxib and NS-398 may account for the different rates of apoptosis observed.

In conclusion, the COX-2 selective inhibitors NS-398 and celecoxib produce dose-dependent growth inhibition of bladder cancer cell lines. However, biologic differences in terms of cell cycle progression and induction of apoptosis were observed for these two agents. Both celecoxib and NS-398 down-

regulated $\mathrm{Bcl}-2$. These changes occurred in cells that do not

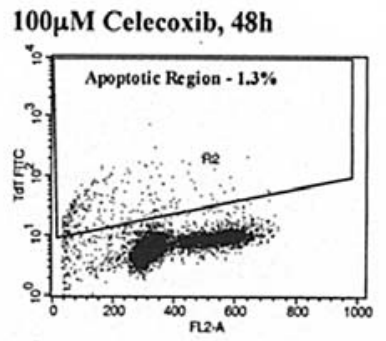



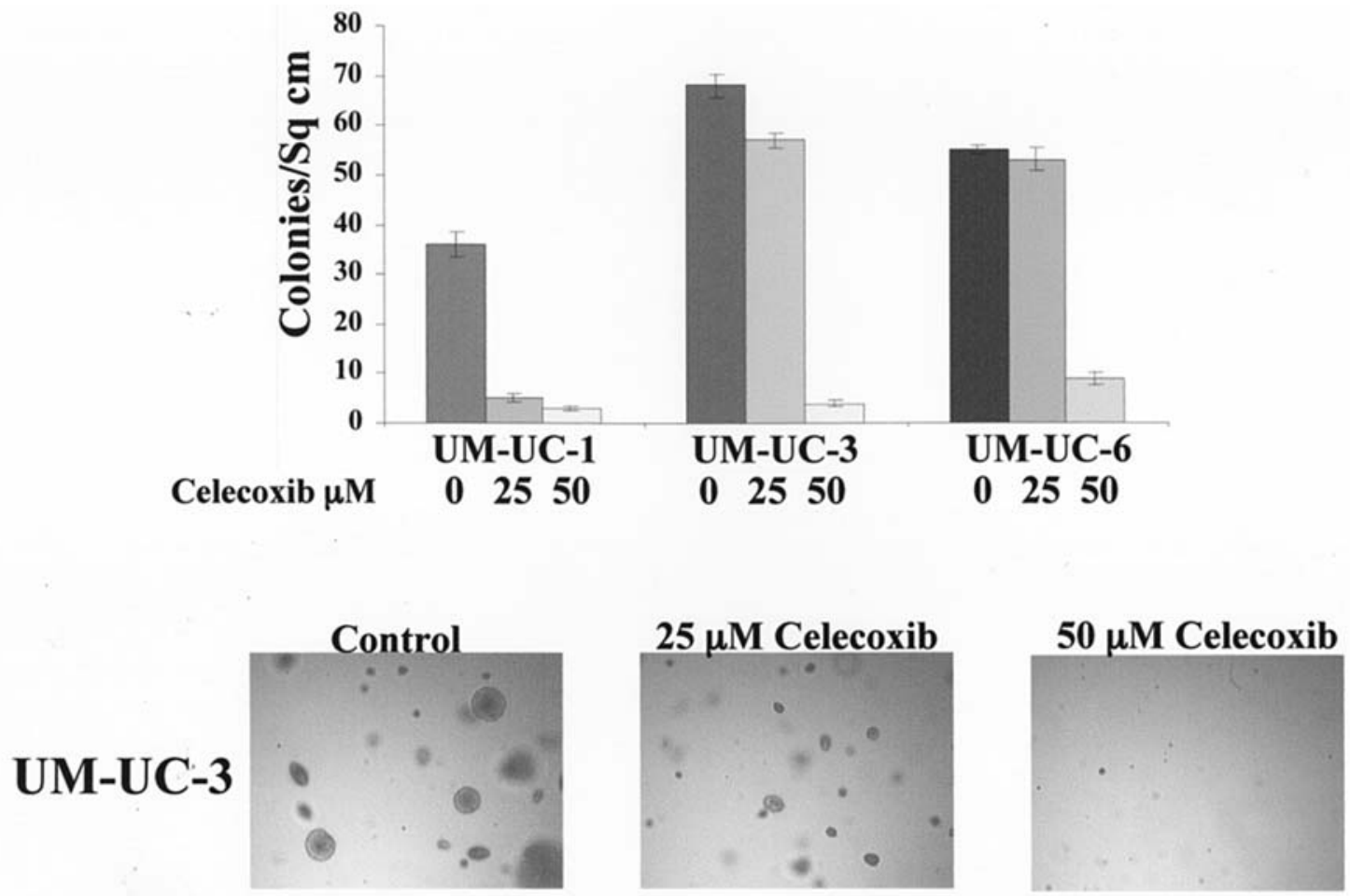

Figure 7. Inhibition of anchorage independent growth-colony formation for UM-UC-3 in the presence of celecoxib treatment.

express COX-2, suggesting an important role for COX-2independent activity for these agents.

\section{Acknowledgements}

This study was supported in part by grant RPG-96-044-04MGO-2 from the American Cancer Society.

\section{References}

1. Thun MJ, Namboodiri MM and Heath CWJ: Aspirin use and reduced risk of fatal colon cancer. N Engl J Med 325: 1593-1596, 1991.

2. Giovanucci E, Rimm EB, Stampfer MJ Colditz GA, Ascherio A and Willet WC: Aspirin use and the risk for colorectal cancer and adenoma in male health professionals. Ann Intern Med 121: 241-246, 1994.

3. Castelao JE, Yuan JM, Gago-Dominguez M, Yu MC and Ross RK: Non-steroidal anti-inflammatory drugs and bladder cancer. Br J Cancer 82: 1364-1369, 2000.

4. DuBois RN, Arbramson SB, Crofford L, Gupta RA, Simon LS, van De Putte LB and Lipsky PE: Cyclooxygenase in biology and disease. FASEB J 12: 1063-1073, 1998.

5. Taketo MM: Cyclooxygenase-2 inhibitors in tumorigenesis (part I). J Natl Cancer Inst 90: 1529-1536, 1998.

6. Steinbach G, Lynch PM, Phillips RK, Wallace MH, Hawk E, Gordon GB, Wakabayashi N, Saunders B, Shen Y, Fujimura T, Su LK and Levin B: The effect of celecoxib, a cyclooxygenase-2 inhibitor, in familial adenomatous polyposis. N Engl J Med 342: 1946-1952, 2000.

7. Giardiello FM, Hamilton SR, Krush AJ, Piantadosi S, Hylind LM, Celano P, Booker SV, Robinson CR and Offerhaus GJ: Treatment of colonic and rectal adenomas with sulindac in familial adenomatous polyposis. N Engl J Med 328: 1313-1316, 1993.

8. Thun MJ, Henley SJ and Patrono C: Nonsteroidal antiinflammatory drugs as anticancer agents: mechanistic, pharmacologic, and clinical issues. J Natl Cancer Inst 94: 252-266, 2002.

9. Okie S: Raising the safety bar - the FDA's coxib meeting. N Engl J Med 352: 1283-1285, 2005.
10. Gee J, Sabichi AL and Grossman HB: Chemoprevention of superficial bladder cancer. Crit Rev Oncol Hematol 43: 277-288, 2002.

11. Blanke CD, Mattek NC, Deloughery TG and Koop DR: A phase I study of 5-fluorouracil, leucovorin, and celecoxib in patients with incurable colorectal cancer. Prostaglandins Other Lipid Mediat 75: 169-172, 2005.

12. Nugent FW, Mertens WC, Graziano S, Levitan N, Collea R, Gajra A, Marshall J and McCann J: Docetaxel and cyclooxygenase- 2 inhibition with celecoxib for advanced non-small cell lung cancer progressing after platinum-based chemotherapy: a multicenter phase II trial. Lung Cancer 48: 267-273, 2005.

13. Dandekar DS, Lopez M, Carey RI and Lokeshwar BL: Cyclooxygenase-2 inhibitor celecoxib augments chemotherapeutic drug-induced apoptosis by enhancing activation of caspase- 3 and -9 in prostate cancer cells. Int $\mathbf{J}$ Cancer 115: 484-492, 2005.

14. Grossman HB, Wedemeyer G, Ren L, Wilson GN and Cox B: Improved growth of human urothelial carcinoma cell cultures. J Urol 136: 953-959, 1986.

15. Baelde HJ, Cleton-Jansen AM, van Beerendonk H, Namba M, Bovee JV and Hogendoorn PC: High quality RNA isolation from tumours with low cellularity and high extracellular matrix component for cDNA microarrays: application to chondrosarcoma. J Clin Pathol 54: 778-782, 2001.

16. Yasojima K, Schwab C, McGeer EG and McGeer PL: Distribution of cyclooxygenase-1 and cyclooxygenase-2 mRNAs and proteins in human brain and peripheral organs. Brain Res 830: 226-236, 1999.

17. Davies MA, Lu Y, Sano T, Fang X, Tang P, LaPushin R, Koul D, Bookstein R, Stokoe D, Yung WK, Mills GB and Steck PA: Adenoviral transgene expression of MMAC/PTEN in human glioma cells inhibits Akt activation and induces anoikis. Cancer Res 58: 5285-5290, 1998 .

18. Tsujii M and DuBois RN: Alterations in cellular adhesion and apoptosis in epithelial cells overexpressing prostaglandin endoperoxidesynthase 2. Cell 83: 493-501, 1995.

19. Tsujii M, Kawano S, Tsuji S, Sawaoka H, Hori M and DuBois RN: Cyclooxygenase regulates angiogenesis induced by colon cancer cells. Cell 93: 705-716, 1998.

20. Tsujii M, Kawano S and Dubois RN: Cyclooxygenase-2 expression in human colon cancer cells increases metastatic potential. Proc Natl Acad Sci USA 94: 3336-3340, 1997. 
21. Sheng H, Shao J, Washington MK, et al: Prostaglandin $\mathrm{E}_{2}$ increases growth and motility of colorectal carcinoma cells. J Biol Chem 276: 18075-18081, 2001.

22. Adam L, Mazumdar A, Sharma T, Jones TR and Kumar R: A three-dimensional and temporo-spatial model to study invasiveness of cancer cells by hergulin and prostaglandin $E_{2}$. Cancer Res 61: 81-87, 2001.

23. Sheng H, Shao J, Morrow JD, Beauchamp RD and DuBois RN: Modulation of apoptosis and $\mathrm{Bcl}-2$ expression by prostaglandin $\mathrm{E}_{2}$ in human colon cancer cells. Cancer Res 58: 362-366, 1998.

24. Brown WA, Skinner SA, Malcontenti-Wilson C, Vogiagis D and O'Brien PE: Non-steroidal anti-inflammatory drugs with activity against either cyclooxygenase 1 or cyclooxygenase 2 inhibit colorectal cancer in a DMH rodent model by inducing apoptosis and inhibiting cell proliferation. Gut 48: 660-666, 2001.

25. Reindeau D, Percival MD, Brideau C, et al: Etoricoxib (MK0663): Preclinical profile and comparison with other agents that selectively inhibit cyclooxygenase-2. J Pharmacol Exp Ther 296: 563-571, 2001.

26. Fitzgerald GA and Patrono C: The coxibs, selective inhibitors of cyclooxygenase-2. N Engl J Med 345: 433-442, 2001.

27. Piazza GA, Rahm ALK, Krutzsch M, Sperl G, Paranka NS, Gross PH, Brendel K, Burt RW, Alberts DS, Pamukcu R and Ahnen DJ: Antineoplastic drugs sulindac sulfide and sulfone inhibit cell growth by inducing apoptosis. Cancer Res 55: 3110-3116, 1995.

28. Williams CS, Watson AJM, Sheng H, Helou R, Shao J and DuBois RN: Celecoxib prevents tumor growth in vivo without toxicity to normal gut: lack of correlation between in vitro and in vivo models. Cancer Res 60: 6045-6051, 2000.

29. Elder DJE, Halton DE, Hague A and Paraskeva C: Induction of apoptotic cell death in human colorectal carcinoma cell lines by a cyclooxygenase-2 (COX-2)-selective nonsteroidal antiinflammatory drug: independence from COX-2 protein expression. Clin Cancer Res 3: 1679-1683, 1997.

30. Tegeder I, Pfeilschifter J and Geisslinger G: Cyclooxygenaseindependent actions of cyclooxygenase inhibitors. FASEB J 15 2058-2072, 2001.
31. Song X, Lin H-P, Johnson AJ, Tseng P-H, Yang Y-T, Kulp SK and Chen C-S: Cyclooxygenase-2, player or spectator in cyclooxygenase-2 inhibitor-induced apoptosis in prostate cancer cells. J Natl Cancer Inst 94: 585-591, 2002.

32. Masferrer JL, Leahy KM, Koki AT, Zweifel BS, Settle SL, Woerner M, Edwards DA, Flickinger AG, Moore RJ and Seibert K: Antiangiogenic and antitumor activities of cyclooxygenase-2 inhibitors. Cancer Res 60: 1306-1311, 2000.

33. Grubbs CJ, Lubet RA, Koki AT, Leahy KM, Masferrer JL, Steele VE, Kelloff GJ, Hill DL and Seibert K: Celecoxib inhibits N-butyl-N-(4-hydroxybutyl)-nitrosamine-induced urinary bladder cancers in male B6D2F1 mice and female Fischer-344 rats. Cancer Res 60: 5599-5602, 2000.

34. Liu XH, Yao S, Kirschenbaum A and Levine AC: NS398, a selective cyclooxygenase-2 inhibitor, induces apoptosis and down-regulates bcl-2 expression in LNCaP cells. Cancer Res 58: 4245-4249, 1998

35. Hsu AL, Ching TT, Wang DS, Song X, Rangnekar VM and Chen CS: The cyclooxygenase- 2 inhibitor celecoxib induces apoptosis by blocking Akt activation in human prostate cancer cells independently of Bcl-2. J Biol Chem 275: 11397-11403, 2000.

36. Nikitakis NG, Hebert C, Lopes MA, Reynolds MA and Sauk JJ: PPARgamma-mediated antineoplastic effect of NSAID sulindac on human oral squamous carcinoma cells. Int J Cancer 98: 817-823, 2002.

37. Shureiqi I, Chen D, Lee JJ, Yang P, Newman RA, Brenner DE, Lotan R, Fischer SM and Lippman SM: 15-LOX-1: a novel molecular target of nonsteroidal anti-inflammatory druginduced apoptosis in colorectal cancer cells. J Natl Cancer Inst 92: 1136-1142, 2000.

38. Shureiqi I, Xu X, Chen D, Lotan R, Morris JS, Fischer SM and Lippman SM: Nonsteroidal anti-inflammatory drugs induce apoptosis in esophageal cancer cells by restoring 15-lipoxygenase-1 expression. Cancer Res 61: 4879-4884, 2001.

39. Johnson AJ, Song X, Hsu A-L and Chen C-S: Apoptosis signaling pathways mediated by cyclooxygenase- 2 inhibitors in prostate cancer cells. Adv Enzyme Regul 41: 221-235, 2001. 